\title{
Antioxidant and Elastase Inhibitor Potential of Petals and Receptacle of Rose Flower (Rosa damascena)
}

\author{
Evi Mawarni ${ }^{1}$, Chrismis Novalinda Ginting ${ }^{1 *}$, Linda Chiuman ${ }^{1}$, Ermi Girsang ${ }^{1}$, Rr. Anisa \\ Siwianti Handayani ${ }^{2}$, and Wahyu Widowati ${ }^{3}$ \\ ${ }^{1}$ Universitas Prima Indonesia, Medan, North Sumatra, Indonesia \\ ${ }^{2}$ Aretha Medika Utama, Biomolecular and Biomedical Research Center, Bandung, West Java, Indonesia \\ ${ }^{3}$ Maranatha Christian University, Bandung, West Java, Indonesia
}

\begin{abstract}
Free radicals can cause damage to cells or tissues, autoimmune diseases, degenerative diseases, or cancer. Therefore, the body needs important substances, namely antioxidants that can help protect the body by reducing negative effect from free radicals. Rose flower (Rosa damascena) has anthocyanin pigment which belongs to flavonoid group which has a function as antioxidant or free radical scavenger. This study aims to determine antioxidant and anti-elastase potentials of rose petals and receptacles. The method used in this study was a qualitative phytochemical test to determine the compounds contained in the Rose Petal Extract (RPE) and Rose Receptacle Extract (RRE), ABTS ((2,2'-azino-bis(3-ethylbenzothiazoline-6-sulfonic acid))-reducing assay to determine antioxidant activity, and antiaging test with anti-elastase assay. RPE and RRE contained flavonoids, phenols, tannins and alkaloids, but did not contain saponins. RPE contained triterpenoids and terpenoids, while RRE contained steroids, but did not contain terpenoids. The inhibitory concentration $\left(\mathrm{IC}_{50}\right)$ values in the ABTS reducing assay were $4.46 \pm 0.34 \mu \mathrm{g} / \mathrm{mL}$ (RPE) and $15.49 \pm 0.23 \mu \mathrm{g} / \mathrm{mL}$ (RRE), while the results of the anti-elastase assay were $17.51 \pm 1.47 \mu \mathrm{g} /$ $\mathrm{mL}$ (RPE) and $58.91 \pm 2.31 \mu \mathrm{g} / \mathrm{mL}$ (RRE). Both RPE and RRE are potent antioxidant and antielastase, and RPE is more active than RRE in these assays.
\end{abstract}

Keywords: ABTS; anti-elastase; free radicals; antioxidant; Rosa damascena

*corresponding author

Email: chrismis@unprimdn.ac.id

\section{INTRODUCTION}

Skin is an elastic outer layer that protects the body from the influence of the human environment, and is the heaviest and widest organ of its size, which is approximately $15 \%$ of body weight, and the skin area of an adult is $1.5 \mathrm{~m}^{2}$. Skin is a vital and essential organ that acts as a mirror of health and life (Djuanda, 2007). Skin is the most visible part of the outermost body that makes us realize the aging process all the time. According to Mukherjee et al. (2011), skin aging is a physiological aging due to the passage of time with increasing age. The other type of skin aging is pathological aging, which is premature aging (photo-aging) due to environmental risks, such as UV rays. The clinical signs include dry skin, rough skin appearance, pigmented skin, deep wrinkles or severe atrophy, telangiectasia, premalignant lesions (Widowati et al., 2018a).

Everyone will experience the aging process. Aging is related to dynamic changes in biological, physiological, environmental, interaction and social processes. Some changes are white hair, decrease of sensory function and daily activities, increase of vulnerability to disease, weakness, or disability. In fact, increase of age is a major risk factor for chronic diseases to humans. The aging process is a natural process and cannot be prevented. The aging process can still be slowed by positive things, such as consuming antioxidants, exercising, eating healthy foods, and avoiding environmental factors, such as pollution, excessive UV light, and chemicals that affect human body emitted by free radicals (Mukherjee et al., 2011; Widowati et al., 2018a).

Repeated exposure to UV radiation can accelerate physical acceleration in the skin and connective tissue through the formation of lipid peroxide, cell contents, and reactive oxygen species (ROS). This has an impact on skin elasticity resulting in the formation of wrinkles, uneven black spots, rough skin, precancerous lesions, skin cancer, and melanoma (Widowati et al., 2017; Widowati et al., 2018a). Antioxidants are substances that replace or prevent oxidation that is cellular oxidation. They bind to ROS, activate detoxification proteins, or prevent the formation of ROS (Miladi and Damak, 2008; Widowati et al., 2018a).

Free radicals can be defined as stand-alone molecules containing unpaired electrons in atomic orbitals. Radicals are unstable and very reactive, and they can 
donate or receive electrons from other molecules, so they act as oxidants or reductors. The target of free radicals is all types of molecules in the body, especially lipids, nucleic acids, and proteins (Lobo et al., 2010). Free radicals are known as the main cause of various chronic and degenerative diseases, including diabetes mellitus, inflammation, stroke, cancer, coronary heart disease, and aging (Patil et al., 2015). Some sources of free radicals that are produced internally are mitochondria, xanthine oxidase, peroxisomes, inflammation, phagocytosis, arachidonic pathways, exercise, and ischemic injury/ reperfusion. While externally produced free radicals are from cigarette smoke, pollutants, radiation, certain drugs, pesticides, industrial solvents, and ozone (Lobo et al., 2010).

Nowadays, the need for skin care is common to everyone, especially for women. Facial skin is a body part that describes the condition of whole body. It is not surprising that today many kinds of beauty products are sold, specifically for lightening products that are sold freely from cheap to expensive. Many skin care products cause mild side effects such as allergies, and there are even products that endanger health to get instant and cheap results. The use of skin lightening products often causes side effects, such as hydroquinone can cause ochronosis side effects. Excessive use of steroids can cause skin thinning, hypertrichosis, and hormonal disorders. Meanwhile, mercury is toxic, and can damage the kidneys and nerves (Arbab and Eltahir, 2010).

As a result, the circulation of various beauty products needs to be watched out as many of them use chemicals that are ultimately harmful to user. So, the medical world now returns to scientific plants that have antioxidant and antiaging effects. Some examples of plants that have antioxidant and antiaging effects are roselle roses (Hisbiscus sabdarifa) (Widowati et al., 2017), jasmine (Jasminum sambac) (Widowati et al., 2018b), ripe sesoot fruit (Garcinia picrorrhiza Miq.) (Utami et al., 2018), black soybeans (Glycine max [L.] Merr) (Asan et al., 2019), dragon fruit peel (Hylocereus polyrhizus) (Liana et al., 2019), pineapple (Vrianty et al., 2019), and zalacca skin (Salacca zalacca (Gaert.) Voss) (Girsang et al., 2019). Sources of antioxidants are mangosteen peel (Garcinia mangostana L.) (Widowati et al., 2014), black tea, green tea, oolong tea (Camelia sinensis L.) (Widowati et al., 2015), green meniran (Phyllanthus niruri) (Rusmana et al., 2017), black soybean (Glycine $\max$ L. Merr) (Asan et al., 2019), dragon fruit peel (Hylocereus polyrhizus) (Liana et al., 2019), pineapple (Vrianty et al., 2019), and zalacca bark (Salacca zalacca (Gaert.) Voss) (Girsang et al., 2019). In addition, plants that are beneficial for health and skin are Aloe vera plants (Surjushe et al., 2008). Roses can be used as ornamental flowers and also have many health benefits (Manganti,
2015). Some chemical compounds contained in roses are citral, citronellol, linalool, nerol, eugenol, phenyl ethyl alcohol, farnesol, nonyl aldekia (Hariana, 2013). While in the Bunga Sakti book, rose petals contain flavonoids as antioxidants, zinc, tannin, astringent, vitamin $\mathrm{A}$, vitamin B, vitamin C, vitamin D, and vitamin E (Khaerani, 2014). Based on the potential of roses containing natural antioxidants, such as bioactive components (flavonoids and phenols), it is necessary to consider further about the antioxidant potential and elastase inhibitory effect of the petals and receptacle of rose flower (Rosa damascena). The background of the authors is to examine natural ingredients that are safe and with affordable costs that can be a choice of natural ingredients in skin care for skin antioxidants and skin lightening. Antioxidant test of 2,2'-azino-bis (3-ethylbenzothiazolin-6-sulfonate) (ABTS) and antiaging (anti-elastase) test would be conducted in order to verify the antioxidant and antiaging activity of rose petal extract (RPE) and rose receptacle extract (RRE).

\section{MATERIALS}

\section{Preparation of $\boldsymbol{R}$. damascena Extract}

Damask roses $(R$. damascena) were picked from Cihideung Rose Farm, West Bandung Regency. The plant was identified in Herbarium Laboratory, Department of Biology, School of Life Science and Technology, Bandung, West Java, Indonesia. Petals and receptacles were sorted and weighed to get the initial fresh weight. They were later oven-dried using food dehydrator, weighed for the dry weight, and homogenized in food processor. The dried materials were then soaked and macerated in $1000 \mathrm{~mL}$ distilled ethanol $70 \%$. The ethanol filtrate was filtered for every $24 \mathrm{~h}$ and remaining dry materials were re-macerated until the filtrate became colourless. Collected filtrates were concentrated using $50{ }^{\circ} \mathrm{C}$ evaporator (Zhengzhou Well-known, RE-201D) to obtain the extract, which later be stored at $-20{ }^{\circ} \mathrm{C}$ until further use. The obtained RPE and RRE were expressed as percentage which is calculated using equation:

$$
\text { Extract yield }(\%)=\frac{\text { Evaporated extract weight }}{\text { Dry weight }} \times 100 \%
$$

The both extract RPE and RRE were later diluted in dimethyl sulfoxide (DMSO) with following concentrations: $5000,2500,1250,625,312.50,156.25$, 1000, 500, 250, 125, 62.50, and $31.25 \mu \mathrm{g} / \mathrm{mL}$. This dilution are later called working concentrations (Mahadi et al., 2019; Vrianty et al., 2019; Siregar et al., 2019; Girsang et al., 2019; Liana et al., 2019; Asan et al., 2019; Prahastuti et al., 2020).

\section{Phytochemical Test}

Phytochemical screening of RPE and RRE were 
evaluated with modified Farnsworth method to identify qualitatively presence of flavonoids, tannins, phenols, steroids/triterpenoids, saponins, terpenoids, and alkaloids as listed below.

Identification of flavonoids - About $10 \mathrm{mg}$ of each extracts was inserted into a test tube and then $\mathrm{Mg}$ and 2 $\mathrm{N} \mathrm{HCl}$ were added. The sample mixture was heated for 5-10 minutes and then cooled and filtered. Then, amyl alcohol solution was added to the filtrate. The reaction is positive if red/orange colour is formed (Mahadi et al., 2019; Vrianty et al., 2019; Siregar et al., 2019; Prahastuti et al., 2020).

Identification of phenols - About $10 \mathrm{mg}$ of each extracts was placed on a drip plate and then $1 \%$ of $\mathrm{FeCl}_{3}$ (Merck 1.03861 .0250 , USA) was added into the sample. The presence of phenols was indicated by green/red/purple/ blue/black colour (Mahadi et al., 2019; Vrianty et al., 2019; Siregar et al., 2019; Prahastuti et al., 2020).

Identification of steroids/triterpenoids - About $10 \mathrm{mg}$ of each extracts was placed on the drip plate and then soaked with acetic acid until the sample was covered. After 10-15 minutes, one drop of absolute sulphuric acid $\left(\mathrm{H}_{2} \mathrm{SO}_{4}\right)$ was added to the sample. The formation of green/blue colour showed the presence of steroids while the red/orange sediment showed the triterpenoid (Mahadi et al., 2019; Vrianty et al., 2019; Siregar et al., 2019; Prahastuti et al., 2020).

Identification of saponins - About $10 \mathrm{mg}$ of each extracts was put into a test tube with water, boiled for 5 minutes and then shaken vigorously. The saponin content was indicated by the presence of foam on the surface of the solution (Mahadi et al., 2019; Vrianty et al., 2019; Siregar et al., 2019; Prahastuti et al., 2020).

Identification of tannins- About $10 \mathrm{mg}$ of each extracts was added with $2 \mathrm{~mL}$ of $2 \mathrm{~N} \mathrm{HCl}$ in a test tube and then heated over a water bath for 30 minutes. The mixture was cooled and filtered. The filtrate was added to amyl alcohol. The reaction is positive if a purple colour is formed (Mahadi et al., 2019; Vrianty et al., 2019; Siregar et al., 2019; Prahastuti et al., 2020).

Identification of terpenoids - About $10 \mathrm{mg}$ of each extracts was placed on a drip plate and then vanillin and $\mathrm{H}_{2} \mathrm{SO}_{4}$ solution were added. The reaction is positive if the colour changes to purple (Mahadi et al., 2019; Vrianty et al., 2019; Siregar et al., 2019; Prahastuti et al., 2020).

Identification of alkaloids - About $10 \mathrm{mg}$ of each extracts was put into a test tube and $10 \%$ of ammonia was added to the sample. Then, chloroform was added to the mixture of sample and two layers of liquid were formed. The lower layer was collected and then transferred to the test tube and inserted into $1 \mathrm{~N} \mathrm{HCl} \mathrm{until} \mathrm{it} \mathrm{formed} \mathrm{two} \mathrm{layers.}$ The top layer was collected and then transferred to a new test tube. Then 1-2 drops of Draggendorf solution was added. The reaction is positive when yellow colour is formed (Mahadi et al., 2019; Vrianty et al., 2019; Siregar et al., 2019; Prahastuti et al., 2020).

\section{ABTS (2,2'-azino-bis(3-ethylbenzothiazoline-6- sulfonic acid)) Antioxidant Scavenging Test}

About $2 \mu \mathrm{L}$ of sample was put into a sample well and a blank well was also prepared. Then, $198 \mu \mathrm{L}$ ABTS was added to the sample well. About $200 \mu \mathrm{L}$ ABTS was also added to other well as negative control. About $200 \mu \mathrm{L}$ DMSO was added to the blank well. Then, the plates were incubated for 6 minutes at $37^{\circ} \mathrm{C}$. Absorbance was measured using a microplate reader at a wavelength of $745 \mathrm{~nm}$ (Widowati et al., 2017; Widowati et al., 2018b; Geeta et al., 2019; Girsang et al., 2020; Prahastuti et al., 2020; Juliana et al., 2020).

$$
\text { Scavenging } \%=(\mathrm{Ac}-\mathrm{As}) / \mathrm{Ac} \times 100
$$

Ac: negative control absorbance (without sample)

As: sample absorbance

\section{Anti-Elastase Inhibition Activity Test}

A total of $5 \mu \mathrm{L}$ elastase was put into control well and sample well. A Tris-HCl buffer (Pharmacia Biotech, 171321-01) of $135 \mathrm{~mL}$ was added to the control well, 125 $\mathrm{mL}$ into the sample well, and $130 \mathrm{~mL}$ into an empty well as blank. The sample well and blank well were added with $10 \mu \mathrm{L}$ sample, then the plates were incubated for 15 minutes at $25^{\circ} \mathrm{C}$. About $10 \mu \mathrm{L} \mathrm{N}$-Sucanyl-Ala-Ala-Alap-nitroanilide (Sigma Aldrich, 54760) was added to each blank, sample and control. The plates were incubated for 15 minutes at $25{ }^{\circ} \mathrm{C}$ using a rotator. Absorbance was measured using a microplate reader at a wavelength of $410 \mathrm{~nm}$ (Widowati et al., 2017; Girsang et al., 2020; Utami et al., 2018; Widowati et al., 2018b; Juliana et al., 2020)

$$
\text { Elastase Inhibitory Activity (\%): } \frac{A c-A s}{A c} \times 100
$$

Ac: control absorbance

As: sample absorbance

\section{Statistical Analysis}

Statistical analysis was conducted using SPSS software (version 20.0). Value was presented as mean \pm standard deviation. Significant differences between the groups were determined using the analysis of variance (One Way ANOVA) followed by Tukey's HSD Post-hoc Test. The results of ABTS and anti-elastase activity tests were evaluated by linear regression analysis. Then the value of Inhibitory Concentration $50\left(\mathrm{IC}_{50}\right)$ was determined. 
Table 1. Qualitative phytochemical screening results of RPE and RRE

\begin{tabular}{lll}
\hline Contents & RPE & RRE \\
\hline Flavonoids & + & + \\
Saponins & - & - \\
Phenols & + & + \\
Tannins & + & + \\
Steroids/Triterpenoids & $-/+$ & $+/-$ \\
Terpenoids & + & - \\
Alkaloids & + & + \\
\hline +: exist, - not exist & &
\end{tabular}

Table 2. IC $_{50}$ values of RPE and RRE ABTS-reduction activities

\begin{tabular}{lllll}
\hline Sample & Equation & $\mathbf{R}^{\mathbf{2}}$ & $\mathbf{I C}_{\mathbf{5 0}}(\mu \mathrm{g} / \mathrm{mL})$ & $\begin{array}{c}\text { Average of } \mathbf{I C}_{\mathbf{5 0}} \\
(\boldsymbol{\mu g} / \mathbf{m L} \mathbf{)}\end{array}$ \\
\hline RPE (replication1) & $\mathrm{y}=1.1128 \mathrm{x}+44.83$ & 0.9932 & 4.65 & \\
RPE (replication 2) & $\mathrm{y}=1.1152 \mathrm{x}+44.788$ & 0.9939 & 4.67 & $4.46 \pm 0.34$ \\
RPE (replication 3) & $\mathrm{y}=1.1016 \mathrm{x}+45.511$ & 0.9967 & 4.07 & \\
RPE (average) & $\mathrm{y}=1.1099 \mathrm{x}+45.043$ & 0.9951 & 4.47 & \\
\hline RRE (replication 1) & $\mathrm{y}=1.5108 \mathrm{x}+26.571$ & 0.9914 & 15.51 & $15.49 \pm 0.23$ \\
RRE (replication 2) & $\mathrm{y}=1.5051 \mathrm{x}+27.047$ & 0.9895 & 15.25 & \\
RRE (replication 3) & $\mathrm{y}=1.52 \mathrm{x}+26.123$ & 0.9933 & 15.71 & \\
RRE (average) & $\mathrm{y}=1.512 \mathrm{x}+26.58$ & 0.9919 & 15.49 & \\
\hline
\end{tabular}

\section{RESULTS}

\section{Preparation of $\boldsymbol{R}$. damascene Extract}

The fresh rose petals and receptacles, which were determined, were each dried using a food dehydrator to produce a sample dry weight. The percentage of RPE yield was $35.4 \%$ and RRE was $3.02 \%$. These results indicate that RRE is better than RPE.

\section{Phytochemical Assay}

Phytochemical testing is a way to qualitatively determine the class of chemical compounds contained in a plant. The choice of solvent and extraction method are the most important factors in carrying out phytochemical tests. Phytochemical tests are carried out by adding a colour reagent, then colour changes occur. The compounds tested were flavonoids, saponins, phenols, tannins, steroids/triterpenoids, terpenoids, and alkaloids. Based on Table 1, it is known that both RPE and RRE contain flavonoids, phenols, tannins, and alkaloids but do not contain saponins. In addition, RPE contains triterpenoids and terpenoids, while RRE contains steroids and does not contain terpenoids.

\section{ABTS Reducing Antioxidant Assay}

ABTS reduction activity test measures the relative ability of antioxidants to trap the produced ABTS. ABTS

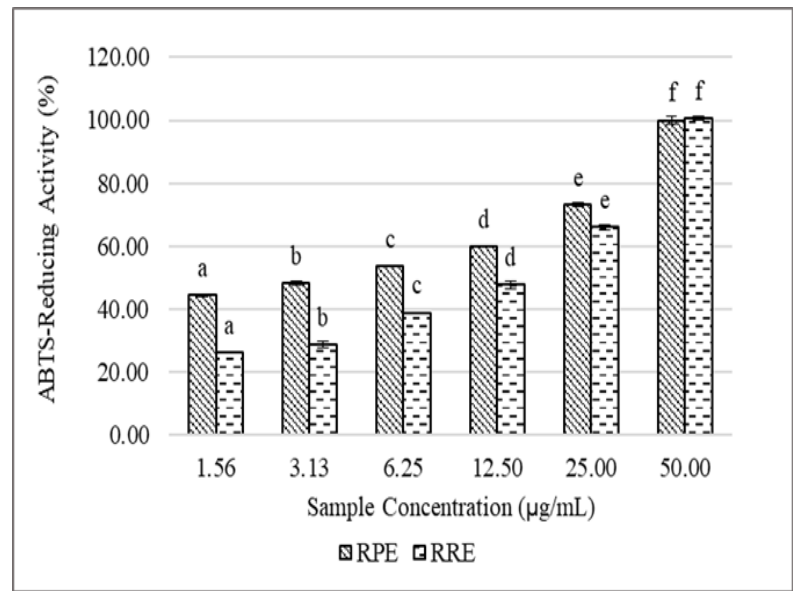

*Data are presented as means \pm standard deviation, letter differences (a, b, c, d, e, f) both on the RPE and RRE samples showing significant differences among concentrations at $\mathrm{P}<0.05$ (Tukey HSD post hoc test)

Figure 1. Effects of various RPE and RRE concentrations on ABTS reduction activity

is produced from the reaction between a strong oxidizing agent (potassium permanganate/potassium persulfate) and ABTS salt. Reduction of ABTS solution in bluegreen by antioxidants that donate hydrogen is measured by the spectrum of long-wave absorption. In the ABTS reduction activity test, the final concentrations of the sample used were $50 \mu \mathrm{g} / \mathrm{mL} ; 25 \mu \mathrm{g} / \mathrm{mL} ; 12.5 \mu \mathrm{g} / \mathrm{mL}$; 
Table 3. IC $_{50}$ values of RPE and RRE anti-elastase activities

\begin{tabular}{lllll}
\hline Sample & Equation & $\mathbf{R}^{2}$ & $\mathbf{I C}_{\mathbf{5 0}}(\mu \mathrm{g} / \mathrm{mL})$ & $\begin{array}{c}\text { Average of IC } \\
(\boldsymbol{\mu g} / \mathbf{m L})\end{array}$ \\
\hline RPE (replication1) & $\mathrm{y}=0.4338 \mathrm{x}+42.09$ & 0.9918 & 18.23 & \\
RPE (replication 2) & $\mathrm{y}=0.4649 \mathrm{x}+41.413$ & 0.9912 & 18.47 & $17.51 \pm 1.47$ \\
RPE (replication 3) & $\mathrm{y}=0.4931 \mathrm{x}+42.199$ & 0.9781 & 15.82 & \\
RPE (average) & $\mathrm{y}=0.4429 \mathrm{x}+41.996$ & 0.9902 & 17.51 & \\
\hline RRE (replication 1) & $\mathrm{y}=0.5967 \mathrm{x}+13.588$ & 0.9966 & 61.02 & $58.91 \pm 2.31$ \\
RRE (replication 2) & $\mathrm{y}=0.6226 \mathrm{x}+13.097$ & 0.9903 & 59.27 & \\
RRE (replication 3) & $\mathrm{y}=0.6564 \mathrm{x}+12.948$ & 0.989 & 56.45 & \\
RRE (average) & $\mathrm{y}=0.6253 \mathrm{x}+13.211$ & 0.9932 & 58.91 & \\
\hline
\end{tabular}

$6.25 \mu \mathrm{g} / \mathrm{mL} ; 3.13 \mu \mathrm{g} / \mathrm{mL}$; and $1.56 \mu \mathrm{g} / \mathrm{mL}$. The results of ABTS reduction activities from RPE and RRE based on $\mathrm{IC}_{50}$ values can be seen in Figure 1.

The effectiveness of $50 \%$ trapping activity $\left(\mathrm{IC}_{50}\right)$ is the concentration required for the sample to trap $50 \%$ of ABTS radical. $\mathrm{IC}_{50}$ values were calculated using linear regression $(y=a+b x)$ obtained from the linear concentration test graph (Widowati et al., 2017; Widowati et al., 2018b; Geeta et al., 2019; Prahastuti et al., 2020; Juliana et al., 2020). $\mathrm{IC}_{50}$ ABTS reduction values can be seen in the following Table 2 .

\section{Antielastase Assay}

The elastase inhibitory activity test used six final sample concentrations of $2.08 \mu \mathrm{g} / \mathrm{mL} ; 4.17 \mu \mathrm{g} / \mathrm{mL} ; 8.33 \mu \mathrm{g} / \mathrm{mL}$; $16.67 \mu \mathrm{g} / \mathrm{mL} ; 33.33 \mu \mathrm{g} / \mathrm{mL}$; and $66.67 \mu \mathrm{g} / \mathrm{mL}$. Elastase inhibition activity by RPE and RRE samples can be seen in Figure 2 below. $\mathrm{IC}_{50}$ of anti-elastase values can be seen in the following Table 3.

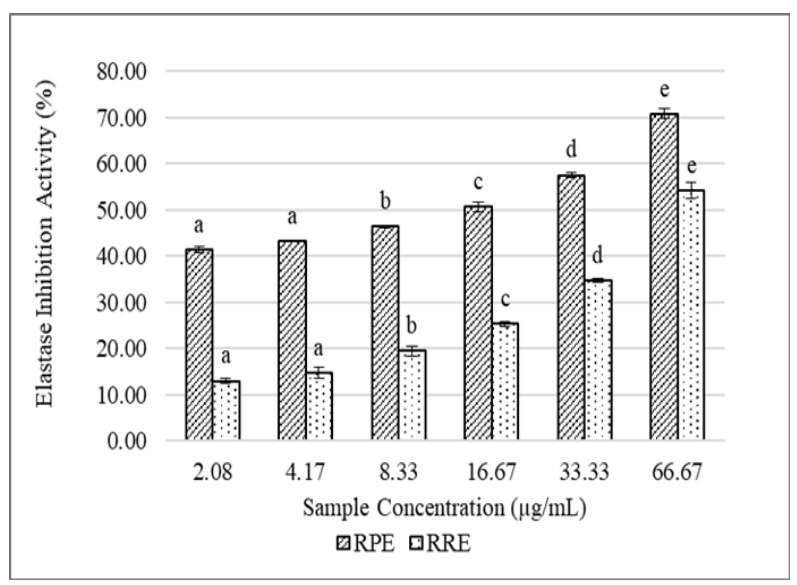

*Data are presented as means \pm standard deviation, letter differences (a, b, c, d, e) both on RPE and RRE samples showing significant differences among concentrations at $\mathrm{P}<0.05$ (Tukey HSD post hoc test)

Figure 2. Effects of various RPE and RRE concentrations on anti-elastase activity

\section{DISCUSSION}

$R$. damascena has benefits as a fragrance and also acts as a drug that is anti-HIV, antibacterial, antioxidant, antitussive, hypnotic, and antidiabetic, and provides a relaxing effect on the trachea. The crown of the rose contains anthocyanin pigment which belongs to the group of flavonoids and a type of anthocyanin cyanidine that has a function of antioxidant or free radical prevention (Patil et al., 2015).

Rose ( $R$. damascena) was separated into the petals and the receptacle. After the separation process, the sample was weighed to determine the wet weight and carried out drying using a food dehydrator to remove the water content in the sample until a simplicia was obtained. Simplicia is then smoothed to facilitate the extraction process.

RPE and RRE were further tested qualitatively for their phytochemical content using the Farnsworth method with modification (Mahadi et al., 2019; Vrianty et al., 2019; Siregar et al., 2019; Prahastuti et al., 2020). Phytochemical test results show that both RPE and RRE contain flavonoids, phenols, tannins and alkaloids, but do not contain saponins. In addition, RPE contains triterpenoids and terpenoids, while RRE contains steroids, but does not contain terpenoids. Tatke et al. (2015) reported the compounds contained in the methanol extract of $R$. damascena are carbohydrates, proteins, glycosides, alkaloids, tannins, phenols, and saponins.

According to Boskabady et al. (2011), secondary metabolite compounds contained in $R$. damascena include flavonoids and terpenoids. However, in this study, there was no terpenoid content in RRE. This can be caused by various factors such as environmental factors when growing the roses to different solvents used in the maceration process (Furnawanthi, 2003; Patel et al., 2012). 
The antioxidant activity test of RPE and RRE in this study was carried out using the ABTS reduction test. The ABTS radical is a chromophore group that has a blue colour. RPE and RRE are able to capture ABTS radical effectively, higher concentration increased ABTS reducing activity compared to control (ABTS radical). In the ABTS test, the ABTS green-blue colour turns yellowish or colourless depending on the hydrogen atom or electron received from the antioxidant. The antioxidant activity of lipid and water soluble compounds can be measured by the ABTS test (Aliakbarlu et al., 2018).

RPE has better ABTS reduction activity when compared to RRE (Figure 1). At the highest concentration (50 $\mu \mathrm{g} / \mathrm{mL}), \mathrm{RPE}$ had a trapping activity of $99.96 \pm 0.11 \%$ followed by RRE of $100.70 \pm 0.32 \%$. In addition, the $\mathrm{IC}_{50}$ value of RPE $(4.46 \pm 0.34 \mu \mathrm{g} / \mathrm{mL})$ is smaller than the $\mathrm{IC}_{50}$ value of RRE $(15.49 \pm 0.23 \mu \mathrm{g} / \mathrm{mL})$. Patil et al., (2015) reported the $\mathrm{IC}_{50}$ value of RPE in ethanol solvents was $325.56 \pm 4.53 \mu \mathrm{g} / \mathrm{mL}$. Meanwhile, the results of the ABTS test conducted by Aliakbarlu et al. (2018) stated that at concentrations of $0.5 \mu \mathrm{g} / \mathrm{mL}$ and $1 \mu \mathrm{g} / \mathrm{mL}$, RPE had ABTS reduction activity of $7.16 \%$. Researches of Patil et al. (2015) and Aliakbarlu et al. (2018) showed lower antioxidant activity than the results of the study. This may be caused by a different extraction method, different content of the extract compound, or lower content of the extract compound.

RPE and RRE contain flavonoids and phenols (Table 1). Phenol and polyphenol compounds such as flavonoids are found in food products derived from plants that have been shown to have significant antioxidant activity. Hidalgo et al. (2010) reported the $\mathrm{EC}_{50}$ values of phenol and flavonoid compounds in the DPPH (2,2-Diphenyl-1picryl hydrazyl) test were $256.2 \pm 9.2 \mu \mathrm{M}$ for quercetin; $274.0 \pm 5.4 \mu \mathrm{M}$ for myricetin; $699.9 \pm 302 \mu \mathrm{M}$ for kaempferol; $369.4 \pm 26.4 \mu \mathrm{M}$ for (-) epicatechin; and $380.6 \pm 15.4 \mu \mathrm{M}$ for catechin.

According to Widowati et al. (2017), the smaller the $\mathrm{IC}_{50}$ value of a sample, the better the ability of the sample to trap free radicals. Meanwhile, according to Molyneux (Marjoni and Zulfisa, 2017), a substance has antioxidant activity if the $\mathrm{IC}_{50}$ obtained ranges from $<50 \mu \mathrm{g} /$ $\mathrm{mL}$ highly active, $50-100 \mu \mathrm{g} / \mathrm{mL}$ active, including the substance that is considered higly active antioxidant for RPE and active antioxidant for RRE.

The antioxidant activity of the RPE and RRE is also estimated to have a correlation with the antiaging activity. In the elastase inhibition test, the RPE has a higher elastase inhibitory activity compared to the RRE (Figure 2). The highest activity was at a concentration of $66.67 \mu \mathrm{g} / \mathrm{mL}$, i.e. the RPE had an activity of $70.80 \pm$ $1.10 \%$, while the RRE was $54.16 \pm 1.71 \% . \mathrm{IC}_{50}$ values of RPE and RRE were $17.51 \pm 1.47 \mu \mathrm{g} / \mathrm{mL}$ and $58.91 \pm$ $2.31 \mu \mathrm{g} / \mathrm{mL}$, respectively.

Karim et al. (2014) tested cocoa powder using the LC/ $\mathrm{MS} / \mathrm{MS}$ method and showed flavonoid content in the extract. After the elastase test, the $\mathrm{IC}_{50}$ value was 3.51 $\mu \mathrm{g} / \mathrm{mL}$. Based on the research results of Xu et al. (2009), the following flavonoid compounds have quite high antioxidant and anti-elastase activity. The $\mathrm{IC}_{50}$ values of amentoflavone and robustaflavone were $1.27 \pm 0.16$ $\mu \mathrm{M}$ and $1.33 \pm 0.21 \mu \mathrm{M}$ for the elastase test, while the ABTS test results were $>100 \mu \mathrm{M}$. Elastase activity rises significantly with age and exerts a reduced effect on skin elasticity and other aging characteristics (Xu et al., 2009). Amla (Phyllanthus emblica) extract, which has higher phenol content $(6.40 \pm 0.88 \mathrm{mg} \mathrm{QE} / \mathrm{g})$ than sapota (Manilkara zapota) and silymarin, is proven to have better DPPH (2,2-diphenyl-1-picryl hydrazyl) trapping value and $\mathrm{ABTS}$ reduction, with $\mathrm{IC}_{50}$ values of $1.70 \pm$ $0.07 \mathrm{mg} / \mathrm{mL}$ and $4.45 \pm 0.10 \mathrm{mg} / \mathrm{mL}$, respectively.

Higher antioxidant property was found in flower petals compared to receptacle due to higher proanthocyanidins and anthocyanins, which are the precursor and main component of color substances in plants. Total nonanthocyanins flavonoids (colorless flavonoids) also markedly higher in petals compared to calyx (del Valle et al., 2015). The antioxidant effect of $R$. damascena and its inhibitory effect on lipid oxidation were evaluated in an in vivo study. The results showed a potent antioxidant and lipid peroxidation inhibitory effects comparable to tocopherol and suggested that the plant could be considered as a medicinal source for the treatment and prevention of many free radical diseases (Shahriari et al., 2007). Plant extract with antioxidant polyphenols can inhibit elastase activity, which can be explained through ROS scavenging theory of skin aging (Horng et al., 2017). Our result shows higher elastase inhibitory activity in rose petals compared to receptacle which is in line with higher ABTS scavenging activity as antioxidant parameter.

\section{CONCLUSIONS}

Based on the research, it is shown that RPE contains flavonoid compounds, phenols, tannins, alkaloids, triterpenoids, and terpenoids, but does not contain saponins, meanwhile RRE contains flavonoid, phenols, tannins, alkaloid, and steroids, but does not contain saponins, triterpenoids, and terpenoids. Antioxidant activities in ABTS-reducing of RPE and RRE based on $\mathrm{IC}_{50}$ values are $4.46 \pm 0.34 \mu \mathrm{g} / \mathrm{mL}$ and $15.49 \pm 0.23 \mu \mathrm{g} /$ $\mathrm{mL}$. Meanwhile, the antiaging activity in anti-elastase inhibition of RPE and RRE based on $\mathrm{IC}_{50}$ values are $17.51 \pm 1.47 \mu \mathrm{g} / \mathrm{mL}$ and $58.91 \pm 2.31 \mu \mathrm{g} / \mathrm{mL}$. RPE is more active than RRE both antioxidant and elastase inhibition. 


\section{ACKNOWLEDGMENT}

This study was funded by Universitas Prima Indonesia. Laboratory facilities and research methodology were supported by Aretha Medika Utama, Biomolecular and Biomedical Research Center, Bandung, Indonesia. We also thank Ubaydillah Zedd Munshy, Rizal Rizal, Wahyu Setia Widodo, Satrio Haryo Benowo Wibowo, Ika Adhani Sholihah, Dewani Tediana Yusepany, Dwi Surya Artie, Riyani Lestari, Hanna Sari Widya Kusuma for their valuable assistance.

\section{REFERENCES}

Aliakbarlu, J., Mohammadi, S., Dehestaniathar, S. \& Khalili Sadaghiani, S. (2018). Effects of dried rose petals (Rosa damascena) on the antioxidant capacity of green and black tea. Journal of Advances in Environmental Health Research, 6(4), 240-245.

Arbab, A.H.H. \& Eltahir, M.M. (2010). Review on skin whitening agents. Khartoum Pharmacy Journal, 13(1), 5-9.

Asan, T., Lister, I.N.E., Fachrial, E., Widowati, W., Samin, B. \& Liena, L. (2019). Potency of black soybean (Glycine $\max$ (L.) Merr) extracted and daidzein as antioxidant and antihyaluronidase. Traditional Medicine Journal, 24(1), 52-58.

Boskabady, M.H., Shafei, M.N., Saberi, Z. \& Amini, S. (2011). Pharmacological effects of Rosa damascena. Iranian Journal of Basic Medical Sciences, 14(4), 295.

del Valle, J.C., Buide, M.L., Casimiro-Soriguer, I., Whittall, J.B. \& Narbona, E. (2015). On flavonoid accumulation in different plant parts: variation patterns among individuals and populations in the shore campion (Silene littorea). Frontiers in Plant Science, 6(1), 939952.

Djuanda, A. (2007). Ilmu penyakit kulit dan kelamin (edisi kelima). Jakarta: Balai Penerbit FKUI.

Furnawanthi, I. (2002). Khasiat dan manfaat lidah buaya si tanaman ajaib. Agromedia Pustaka, Jakarta.

Geeta, G., Widodo, W.S., Widowati, W., Ginting, C.N., Lister, I.N.E., Armansyah, A., Girsang, E. (2019). Comparison of Antioxidant and Anti-collagenase Activity of Genistein and Epicatechin. Pharmaceutical Sciences and Research, 6(2), 111-117.

Girsang, E., Lister, I.N.E., Ginting, C.N., Khu, A., Samin, B., Widowati, W., Wibowo, S. \& Rizal, R.
(2019). Chemical constituents of snake fruit (Salacca zalacca (Gaert.) Voss) peel and in silico antiaging analysis. Molecular and Cellular Biomedical Sciences, 3(2), 122-128.

Girsang, E., Lister, I.N.E., Ginting, C.N., Sholihah, I. A., Raif, M., A., Kurniadi, S., Million, H., \& Widowati, W. (2020). Antioxidant and antiaging activity of rutin and caffeic acid. Pharmaciana, 10(2):147-156

Hariana, H.A. (2013). Tumbuhan obat dan khasiatnya. Penebar Swadaya Grup, Jakarta, 262.

Hidalgo, M., Sánchez-Moreno, C., \& de Pascual-Teresa, S. (2010). Flavonoid-flavonoid interaction and its effect on their antioxidant activity. Food Chemistry, 121(3), 691-696.

Horng, C.T., Wu, H.C., Chiang, N.N., Lee, C.F., Huang, Y.S., Wang, H.Y., Yang, J.S., \& Chen, F.A. (2017). Inhibitory effect of burdock leaves on elastase and tyrosinase activity. Experimental and Therapeutic Medicine, 14(4), 3247-3252.

Juliana, C., Lister, I.N.E., Girsang, E., Nasution, A.N., \& Widowati, W. (2020). Antioxidant and elastase inhibitor from black soybean (Glycine max L.) and its compound (daidzein). Journal of Biomedicine and Translational Research, 6(1), 11-14.

Karim, A.A., Azlan, A., Ismail, A., Hashim, P., Abd Gani, S.S., Zainudin, B.H. \& Abdullah, N.A. (2014). Phenolic composition, antioxidant, anti-wrinkles and tyrosinase inhibitory activities of cocoa pod extract. $B M C$ Complementary and Alternative Medicine, 14(381):1-13

Khaerani, U. (2014). Bunga sakti basmi berbagai penyakit, Dunia sehat, Yogyakarta

Liana, L., Rizal, R., Widowati, W., Fioni, F., Akbar, K., Fachrial, E. \& Lister, I.N.E. (2019). Antioxidant and anti-hyaluronidase activities of dragon fruit peel extract and kaempferol-3-o-rutinoside. Jurnal Kedokteran Brawijaya, 30(4), 247-252.

Lobo, V., Patil, A., Phatak, A. \& Chandra, N. (2010). Free radicals, antioxidants and functional foods: Impact on human health. Pharmacognosy Reviews, 4(8), 118126.

Mahadi, S.B., Handayani, R.A.S., Widowati, W., Wilsen, W., Dewani, Y., Fachrial, E., \& Lister, I.N.E. (2019). Antioxidant and anti-tyrosinase activities of Aloe vera rind and gel extracts. Global Medical \& Health Communication, 7(3), 170-176. 
Manganti, Irena. (2015). 40 resep ampuh tanaman obat untuk mengobati jantung koroner dan menyembuhkan stroke. Yogyakarta: Araska.

Miladi, S. \& Damak, M. (2008). In vitro antioxidant activities of Aloe vera leaf skin extracts. Journal de la Société Chimique de Tunisie, 10, 101-109.

Molyneux, P. (2004). The use of the stable free radical diphenylpicrylhydrazyl (DPPH) for estimating antioxidant activity. Songklanakarin Journal of Science and Technology, 26(2), 211-219.

Marjoni, M.R. \& Zulfisa, A. (2017). Antioxidant activity of methanol extract/fractions of Senggani leaves (Melastoma candidum D. Don).Pharmaceutica Analytica Acta. 8(8),1-6

Mukherjee, P.K., Maity, N., Nema, N.K. \& Sarkar, B.K. (2011). Bioactive compounds from natural resources against skin aging. Phytomedicine, 19(1), 64-73.

Patel, D.K., Patel, K. \& Dhanabal, S.P. (2012). Phytochemical standardization of Aloe vera extract by HPTLC techniques. Journal of Acute Disease, 1(1), 4750.

Patil, P.S., Tatke, P.A. \& Gabhe, S.Y. (2015). In vitro antioxidant and free radical scavenging activity of extracts of Rosa damascena flower petals. American Journal of Phytomedicine and Clinical Therapeutics, 3(9), 589-601.

Prahastuti, S., Hidayat, M., Hasiana, S.T., Widowati, W., Widodo, W.S., Handayani, A.S., Rizal, R., \& Kusuma, H. S. W. (2020). The ethanol extract of the bastard cedar (Guazuma ulmifolia L.) as antioxidants. Pharmaciana, 10(1), 77-88.

Rusmana, D., Wahyudianingsih, R., Elisabeth, M., Balqis, B., Maesaroh, M., \& Widowati, W. (2017). Antioxidant activity of Phyllanthus niruri extract, rutin and quercetin. The Indonesian Biomedical Journal, 9(2), 84-90.

Shahriari, S., Yasa, N., Mohammadirad, A., Khorasani, R., \& Abdollahi, M. (2007). In vivo antioxidant potentials of Rosa damascene petal extract from Guilan, Iran, comparable to alpha-tocopherol. International Journal of Pharmacology, 3(2), 187-190.

Siregar, I.D., Kusuma, H.S.W., Widowati, W., Marpaung, H.H., Ferdinand, S., Fachrial, E., \& Lister, I.N.E., (2019). Antioxidant and Antityrosinase Activities of Ethanolic Pachyrhizuserosus Peel and Tuber Extract. Majalah Kedokteran Bandung, 51(2), 75-81.
Surjushe, A., Vasani, R., \& Saple, D.G. (2008). Aloe vera: A short review. Indian Journal of Dermatology, 53(4), 163-166.

Tatke, P., Satyapal, U. S., Mahajan, D. C., \& Naharwar, V. (2015). Phytochemical analysis, in-vitro antioxidant and antimicrobial activities of flower petals of Rosa damascena. International Journal of Pharmacognosy Phytochemical Research, 7(2), 246-250.

Utami, S., Sachrowardi, Q.R., Damayanti, N.A., Wardhana, A., Syarif, I., Nafik, S., Arrahmani, B.C., Kusuma, H.S.W., \& Widowati, W. (2018). Antioxidants, anticollagenase and antielastase potentials of ethanolic extract of ripe sesoot (Garcinia picrorrhiza Miq.) fruit as antiaging. Journal of HRR Eed Pharmacology, 7(2), 88-93.

Vrianty, D., Qodariah, R.L., Widowati, W., Sinaga, A.P.F., Fibrina, D., Fachrial, E., \& Lister, I.N.E., 2019. Comparison of antioxidant and anti-tyrosinase activities of pineapple (Ananas comosus) core extract and luteolin compound. Jurnal Kedokteran Brawijaya, 30(4), 240246.

Widowati, W., Noverina, R., Ayuningtyas, W., Kurniawan, D., Faried, A., Laksmitawati, D.R., Rihibiha, D.D., Rizal, R., Suciati, T., \& Sumitro, S.B. (2018a). Reactive oxygen species (ROS), mechanisms and role in health and disease: Reactive oxygen species and aging mechanism (Chapter 3). New York: Nova Science Publishers, Inc. 101-134.

Widowati, W., Janeva. B, W. Nadya, S., Amalia, A., Arumwardana, S., Kusuma, H.S.W., \& Arinta, Y. (2018b). Antioxidant and antiaging activities of Jasminum sambac extract, and its compounds. Journal of Reports in Pharmaceutical Science, 7 (3), 270-285.

Widowati, W., Rani, A.P., Hamzah, R.A., Arumwardana, S., Afifah, E., Kusuma, H.S.W., Rihibiha, D.D., Nufus, H., \& Amalia, A. (2017). Antioxidant and antiaging assays of Hibiscus sabdariffa extract and its compounds. Natural Product Sciences, 23(3), 192-200.

Widowati, W., Fauziah, N., Herdiman, H., Afni, M., Afifah, E., Kusuma, H.S.W., Nufus, H., Arumwardana, S., \& Rihibiha, D.D. (2016). Antioxidant and anti-aging assays of Oryza sativa extracts, vanillin and coumaric acid. Journal of Natural Remedies, 16(3), 88-99.

Widowati, W., Herlina, T., Ratnawati, H., Constantia, G., Deva, I.D.G.S., \& Maesaroh, M. (2015). Antioxidant potential of black, green and oolong tea methanol extracts. Biology, Medicine \& Natural Product Chemistry, 4(2), 35-39. 
Widowati, W., Darsono, L., Suherman, J., Yelliantty, Y., \& Maesaroh, M. (2014). High performance lipid chromatography (HPLC) analysis, antioxidant, antiaggregation of mangosteen peel extract (Garcinia mangostana L.). International Journal of Bioscience, Biochemical and Bioinformatics, 4(6), 458-466.

Xu, G.H., Ryoo, I.J., Kim, Y.H., Choo, S.J. \& Yoo, I.D. (2009). Free radical scavenging and antielastase activities of flavonoids from the fruits of thuja orientalis. Archives of Pharmacal Research, 32(2), 275-282. 